\title{
THE EFFECT OF DIFFERENT STARTER CULTURES ON THE FERMENTATION OF YOGURT ADDED WITH AQUEOUS EXTRACT OF WHITE OYSTER MUSHROOM (Pleurotus ostreatus)
}

\author{
Sjaloom E. Sakul ${ }^{1)}$, Djalal Rosyidi*2), Lilik Eka Radiati' ${ }^{2)}$, Purwadi Purwadi'2) \\ 1) Doctoral Program, Faculty of Animal Science, Universitas Brawijaya, Malang, East Java, \\ 65145, Indonesia \\ 2) Faculty of Animal Science, Universitas Brawijaya, Malang, East Java, 65145, Indonesia \\ E-mail: djalal_tht@ub.ac.id
}

Submitted 15 January 2020; Accepted 10 February 2020

\begin{abstract}
The objective of this study was to evaluate the effect of different starter cultures on the fermentation of yogurt added with aqueous extract of white oyster mushroom (Pleurotus ostreatus) whether each starter culture respond differently. This study used a completely randomized design (CRD) with 3 treatments and 4 replications. Yogurt was made with one of the starter cultures as treatment: Streptococcus thermophilus (ST), Lactobacillus acidophilus (LA), or Lactobacillus bulgaricus (LB). Data were analyzed using analysis of variance followed by the least significant difference test. The variables tested were $\mathrm{pH}$, total acid content, viscosity and total lactic acid bacteria. The results showed that yogurt made with ST had lower $\mathrm{pH}$ and total acid than the others. The use of LB resulted in higher total acid content. The addition of different starter cultures in yogurt did not influence viscosity. Among starter cultures, the use of LA resulted in higher total lactic acid bacteria (LAB) than the others. However, the number of LAB from different treatments were not much different (within the range of $7 \log \mathrm{CFU} / \mathrm{mL}$ ). It is suggested that the three starter cultures are adaptive and capable to fermenting yogurt added with aqueous extract of white oyster mushroom (Pleurotus ostreatus).
\end{abstract}

Key words: Fermentation; mono starter; oyster mushroom; starter activity 


\section{INTRODUCTION}

Yogurt is one of fermented dairy products that offers health benefits for human. It is produced through the fermentation process carried out by lactic acid bacteria (LAB), Streptococcus sulvarius subsp. thermophilus and Lactobacillus delbrueckii subsp. bulgaricus. The fortification of Lactobacillus acidophilus, a probiotic LAB, to yogurt has been also applied to produce probiotic yogurt (Lisko et al., 2017). The quality of yogurt depends on the quality of milk, fermentation time, incubation temperature, and starter cultures (Hapsah and Astriana, 2012).

During fermentation, the cell of LAB converts lactose in milk into organic acids, e.g. lactic acid, and energy, thus reducing $\mathrm{pH}$ of the yogurt (Afriani, 2010). Yogurt can also be fortified with other functional ingredients that can improve the quality and nutrition value of yogurt. The acidity level of yogurt and storage conditions, in some cases, can reduce the viscosity of yogurt, resulting the appearance of syneresis or whey released. In order to maintain the acceptable viscosity of yogurt during storage, food stabilizer is added into the formulation. Food stabilizer for dairy products is made from protein concentrate, gelatin, starch and other polysaccharides (Clark et al., 2014). Yogurt, which is made with food stabilizer, has acceptable viscosity without syneresis during display (Skryplonek et al., 2019). Food stabilizer, which is made from polysaccharide, can play a role as prebiotic too. White oyster mushroom (Pleurotus ostreatus) can be utilized to produce natural food stabilizer as it contains $\beta$-glucan (Tjokrokusumo, 2010). $\beta$-glucan derived from mushroom is one of dietary fibers that offers health benefits for human as it plays a role as prebiotic in human gut (Widyastuti et al., 2011). Pranamuda et al. (2012) mentioned that 164 $\mathrm{g}$ of $\beta$-glucan can be extracted from $28 \mathrm{~kg}$ of Pleurotus ostreatus.

Many studies have revealed the functionality of $\beta$-glucan, e.g. as immunomodulator, reduce plasma cholesterol, prevent colorectal cancer, hypertension, obesity and diabetes (Lambeau and McRorie, 2017). Lazaridou et al. (2014) reported that $\beta$-glucan extracted from wheat improves acceptability and visocity, prevents syneresis and reduces calories without altering the $\mathrm{pH}$ of yogurt. The utilization of Pleurotus ostreatus has been studied previously in low-fat yogurt and yogurt drink (Vital et al., 2015; Anissa and Radiati, 2018).

However, there is no information regarding the ability of $\mathrm{LAB}$ to fermenting yogurt containing aqueous extract of Pleurotus ostreatus. Therefore, the objective of this study was to evaluate the effect of different starter cultures on the fermentation of yogurt added with aqueous extract of white oyster mushroom (Pleurotus ostreatus) whether each starter culture respond differently.

\section{MATERIALS AND METHODS}

\section{Pleurotus ostreatus aqueous extract preparation}

The mushroom was soaked in water, rinsed and drained. Distilled water was added to mushroom (1:1, weght/weight) and homogenized for $10 \mathrm{~min}$ using food blender with maximum speed. The mushroom slurry was pasteurized at $75^{\circ} \mathrm{C}$ for $30 \mathrm{~min}$, cooled
*Corresponding author:

Djalal Rosyidi

Email:djalal_tht@ub.ac.id

Faculty of Animal Science, Universitas Brawijaya,

Malang, East Java, 65145, Indonesia
How to cite:

Sakul, S. E., Rosyidi, D., Radiati, L. E., \& Purwadi, P. (2020). The Effect of Different Starter Cultures on the Fermentation of Yogurt Added with Aqueous Extract of White Oyster Mushroom (Pleurotus ostreatus). Jurnal Ilmu Dan Teknologi Hasil Ternak, 15(1) 46-51 
down to $45^{\circ} \mathrm{C}$ and filtered with filter cloth. Pleurotus ostreatus aqueous extract was immediately used for yogurt manufacture.

\section{Yogurt preparation}

Yogurt was made according to a method described by Tamime and Robinson (2014). Briefly, milk obtained from Friesian Holstein cow was added with different levels of Pleurotus ostreatus aqueous extract at 3\% (volume/volume), pasteurized at $85^{\circ} \mathrm{C}$ for $15 \mathrm{~min}$, cooled down to $45^{\circ} \mathrm{C}$. Each starter culture: Lactobacillus bulgaricus, Streptococcus thermophilus, and Lactobacillus acidophilus, was diluted in $30 \mathrm{~mL}$ of pasteurized milk, added to the rest of pasteurized milk separately, and mixed for $10 \mathrm{~min}$. The inoculated milk was incubated at $27^{\circ} \mathrm{C}$ for $18 \mathrm{~h}$. Physicochemical and microbiological analyses were performed immediately after incubation.

\section{Viscosity, total acid content and $\mathrm{pH}$ measurement}

Yogurt viscosity was measured using Brooke Field viscometer (AMTEK Brookfield, Middleboro, MA) with spindle No. 6 at $20 \mathrm{rpm}$. Yogurt was stirred for 5 min. Viscosity (cP) was calculated as measurement unit shown in viscometer multiplied with 1000. Total acid content equivalent with lactic acid content was determined by titrating $20 \mathrm{~mL}$ of the samples (added with 2 drops of $1 \%$ phenolphthalein) with $0.1 \mathrm{~N} \mathrm{NaOH}$ until the color changes into pink. Total acid content (\%) was calculated according to AOAC method (AOAC, 2005). Syneresis was determined using centrifugation method (Robitaille et al., 2009). The $\mathrm{pH}$ of the sample was determined in duplicate using a calibrated $\mathrm{pH}$ meter.

\section{Lactic acid bacteria measurement}

The number of lactic acid bacteria (LAB) was estimated by plating on MRS agar media. Plates were incubated at $30^{\circ} \mathrm{C}$ for $48 \mathrm{~h}$, under anaerobic conditions. Total lactic acid bacteria were counted and expressed as $\log \mathrm{CFU} / \mathrm{mL}$.

\section{Statistical analysis}

This study employed a completely randomized design. The effect of different starter cultures on the fermentation of yogurt added with Pleurotus ostreatus aqueous extract was observed using one-way analysis of variance. When significant, mean differences $(p<0.05)$ were determined using least significant different test (Subali, 2010).

\section{RESULTS AND DISSCUSION}

\section{pH value}

The $\mathrm{pH}$ value of the yogurt added with Pleurotus ostreatus aqueous extract and fermented by different starter cultures was significantly different $(\mathrm{P}<0.01)$. Yogurt fermented by Streptococcus thermophilus had the lowest $\mathrm{pH}$ among others. While, the $\mathrm{pH}$ of yogurt fermented by Lactobacillus acidophilus and Lactobacillus bulgaricus showed no differences. Dahlan and Sani (2017) reported that the fermentation rate of Streptococcus thermophilus is faster than other LAB used as yogurt starter culture. The $\mathrm{pH}$ of Pleurotus ostreatus aqueous extract and milk used for yogurt production in this study was 4.8 and 6.5 , respectively. Burton et al. (2014) mentioned that $\mathrm{pH}$ value reflects the amount of ion $\mathrm{H}^{+}$from organic acids in fermented milk as a result of bacterial growth.

In preliminary study, the addition of a combined starter cultures consisting of Lactobacillus bulgaricus, Streptococcus thermophilus and Lactobacillus acidophilus to yogurt added with Pleurotus ostreatus aqueous extract resulted in $\mathrm{pH}$ ranged from 4.0 to 4.1 , which is lower than the $\mathrm{pH}$ value found in present study. Streptococcus thermophilus plays a role to convert lactose into lactic acid.

However, it requires valine to promote the growth of Streptococcus thermophilus. Valine is an amino acid produced by Lactobacillus bulgaricus during fermentation as one of its metabolites (Burton et al., 2014). Therefore, the addition 
of mono starter in yogurt production does not optimize the fermentation of milk.

\section{Total acid content}

The total acid content of the yogurt added with Pleurotus ostreatus aqueous extract and fermented by different starter cultures was significantly different $(\mathrm{P}<0.01)$. Yogurt fermented by Lactobacillus bulgaricus had the highest total acid content, followed by that fermented by Lactobacillus acidophilus and Streptococcus thermophilus. Microorganisms require energy derived from carbohydrate, protein and fat found in food. The production rate of lactic acid during fermentation is influenced by the species of starter culture (Afriani, 2010). Fatmawati et al. (2013) mentioned that Lactobacillus bulgaricus converts lactose in milk into lactic acid.

The addition of carbohydrate source, e.g. Pleurotus ostreatus aqueous extract, in milk could possibly optimize the fermentation of yogurt by mono starter culture. However, the amount of acid produced was less than $0.4 \%$, which is not enough for achieving the yogurt's typical tangy taste. The acceptable range of total acid content in yogurt is between $0.5 \%$ to $2.0 \%$ according national standard (BSN, 2009).

Table 1. The $\mathrm{pH}$, total acid content, viscosity and total lactic acid bacteria of yogurt added with Pleurotus ostreatus aqueous extract and fermented by different starter cultures

\begin{tabular}{lccc}
\hline Variable & \multicolumn{3}{c}{ Species } \\
\cline { 2 - 4 } & $\begin{array}{c}\text { Streptococcus } \\
\text { thermophilus }\end{array}$ & $\begin{array}{c}\text { Lactobacillus } \\
\text { acidophilus }\end{array}$ & $\begin{array}{c}\text { Lactobacillus } \\
\text { bulgaricus }\end{array}$ \\
\hline $\mathrm{pH}$ & $4.60 \pm 0.14^{\mathrm{a}}$ & $4.87 \pm 0.03^{\mathrm{b}}$ & $4.88 \pm 0.04^{\mathrm{b}}$ \\
Total acid content (\%) & $0.21 \pm 0.01^{\mathrm{a}}$ & $0.33 \pm 0.02^{\mathrm{b}}$ & $0.37 \pm 0.01^{\mathrm{c}}$ \\
Viscosity (cP) & $14.5 \pm 1.91^{\mathrm{a}}$ & $20.5 \pm 2.08^{\mathrm{a}}$ & $10.0 \pm 1.63^{\mathrm{a}}$ \\
Total lactic acid bacteria $(\log$ CFU/g) & $7.37 \pm 0.04^{\mathrm{a}}$ & $7.52 \pm 0.02^{\mathrm{c}}$ & $7.38 \pm 0.18^{\mathrm{b}}$ \\
\hline
\end{tabular}

Data are shown as mean \pm standard deviation. Different superscripts in the same column indicate a highly significant effect $(\mathrm{P}<0.01)$.

\section{Viscosity}

The viscosity of the yogurt added with Pleurotus ostreatus aqueous extract and fermented by different starter cultures was not significantly different. The viscosity of yogurt is affected by $\mathrm{pH}$, protein content, starter culture strain, incubation time and milk total solid content (Purbasari et al., 2014). This suggests that the addition of mono starter; Lactobacillus bulgaricus, Streptococcus thermophilus, and Lactobacillus acidophilus in yogurt added with Pleurotus ostreatus aqueous extract does not optimize the fermentation as the viscosity of yogurt in this study is close to the viscosity of water $\left(1 \mathrm{cP}\right.$ at $\left.25^{\circ} \mathrm{C}\right)$.

\section{Total lactic acid bacteria}

The total lactic acid bacteria in the yogurt added with Pleurotus ostreatus aqueous extract and fermented by different starter cultures was significantly different $(\mathrm{P}<0.01)$. Yogurt fermented by Lactobacillus acidophilus had the highest total lactic acid bacteria, followed by that fermented by Lactobacillus bulgaricus and Streptococcus thermophilus.

Total lactic acid bacteria is an indicator of microbiological quality of yogurt. The growth of Lactobacillus bulgaricus and Streptococcus thermophilus in yogurt is associated with symbiosis mutualism. These bacteria did not grow as well as Lactobacillus acidophilus when being used as mono starter for yogurt production. Lactobacillus acidophilus could grow independently resulting a higher number of lactic acid bacteria than other treatments. Although the number was significantly different, the range was still around $7 \log \mathrm{CFU} / \mathrm{g}$. The number of lactic acid bacteria in this study is in line with the 
national standard, i.e. 7 log CFU/g (BSN, 2009). This indicates that Streptococcus thermophilus, Lactobacillus acidophilus, and Lactobacillus bulgaricus are adaptive and capable to fermenting yogurt added with Pleurotus ostreatus aqueous extract.

\section{CONCLUSION}

Three different starter cultures used in this study; Streptococcus thermophilus, Lactobacillus acidopillus, and Lactobacillus bulgaricus are adaptive and capable to fermenting yogurt added with Pleurotus ostreatus aqueous extract. The fermentation of yogurt added with Pleurotus ostreatus aqueous extract using three different mono starter cultures resulted in different yogurt characteristics in terms of acidity, viscosity and total lactic acid bacteria.

\section{ACKNOWLEDGMENT}

The authors would like to thank Directorate General of Higher Education of the Republic of Indonesia (DIKTI) for Beasiswa Pendidikan Pascasarjana Dalam Negeri (BPPDN).

\section{REFERENCES}

Afriani, A. (2010). Pengaruh penggunaan starter bakteri asam laktat lactobacillus plantarum dan lactobacillus fermentum terhadap total bakteri asam laktat, kadar asam dan nilai $\mathrm{pH}$ dadih susu sapi. Jurnal Ilmiah Ilmu-Ilmu Peternakan, 13(6), 279-285. https://doi.org/10.22437/JII IP.V0I0.114

Anissa, D., \& Eka Radiati, L. (2018). Effect of the addition of white oyster mushroom (Pleurotus ostreatus) extract on the manufacture of yogurt drink in terms of physical quality. Jurnal Ilmu Dan Teknologi Hasil Ternak, 13(2), 118-125. https://doi. org/10.21776/ub.jitek.2018.013.02.6
AOAC. (2005). Analysis of Official Analytical Chemistry Methods (18th ed.). Washington DC: AOAC International.

Badan Standardisasi Nasional. (2009). Yogurt. Jakarta.

Burton, E., Arief, I. I., \& Taufik, E. (2014). Functional properties of carbonated probiotic yogurt. Jurnal Ilmu Produksi Dan Teknologi Hasil Peternakan, 2(1), 213-218.

Clark, S., Jung, S., \& Lamsal, B. (2014). Food Processing: Principle and Application. West Sussex: John Wiley and Sons.

Dahlana, H. A., \& Sania, N. A. (2017). The interaction effect of mixing starter cultures on homemade natural yogurt's $\mathrm{pH}$ and viscosity. International Journal of Food Studies, 6(2), 152-158. https://doi.org/10.74 55/ijfs/6.2.2017.a3

Fatmawati, U., Prasetyo, F., T.A, M. S., \& Utami, A. N. (2013). Karakteristik yogurt yang terbuat dari berbagai jenis susu dengan penambahan kultur campuran Lactobacillus bulgaricus dan Streptococcus thermophilus. Bioedukasi, 6(2), 1-9.

Lambeau, K. V., \& McRorie, J. W. (2017). Fiber supplements and clinically proven health benefits. Journal of the American Association of Nurse Practitioners, 29(4), 216-223. https:// doi.org/10.1002/2327-6924.12447

Lazaridou, A., Serafeimidou, A., Biliaderis, C. G., Moschakis, T., \& Tzanetakis, N. (2014). Structure development and acidification kinetics in fermented milk containing oat $\beta$-glucan, a yogurt culture and a probiotic strain. Food Hydrocolloids, 39, 204-214. https:// doi.org/10.1016/j.foodhyd.2014.01.015 
Lisko, D., Johnston, G., \& Johnston, C. (2017). Effects of dietary yogurt on the healthy human gastrointestinal (GI) microbiome. Microorganisms, 5(1), 6. https://doi.org/10.3390/micro organisms 5010006

Pelaes Vital, A. C., Goto, P. A., Hanai, L. N., Gomes-da-Costa, S. M., de Abreu Filho, B. A., Nakamura, C. V., \& Matumoto-Pintro, P. T. (2015). Microbiological, functional and rheological properties of low fat yogurt supplemented with Pleurotus ostreatus aqueous extract. $L W T$ - Food Science and Technology, 64(2), 10281035. https://doi.org/10.1016/j.lwt.20 15.07.003

Pranamuda, H., Giarni, R., \& Pranada, A. (2012). Aplikasi $\beta$-glukan sebagai bahan berkhasiat imunomodulator dan anti kanker. In Paper presented at Seminar Insentif Riset Sistem Inovasi Nasional (pp. 70-73). Jakarta.

Purbasari, A., Pramono, Y. B., \& Muhammad, B. (2014). Nilai $\mathrm{pH}$, kekentalan , citarasa asam, dan kesukaan pada susu fermentasi dengan perisa alami jambu air (Syzygium sp). Jurnal Aplikasi Teknologi Pangan, 3(4), 174-177.

Radiati, L. E., Jaya, F., Oktavianingsih, D. E., \& Fayca. (2016). The Effect Of Super Red Dragon Fruit (Hylocereus Costaricensis) Peels On Physico Chemical, Antioxidant And Microstructure Of Chicken Saussage. In Paper presented at The 17th AsianAustralasian Association of Animal Production Societies Animal Science Congress (pp. 845-850). Fukuoka.
Robitaille, G., Tremblay, A., Moineau, S., St-Gelais, D., Vadeboncoeur, C., \& Britten, M. (2009). Fat-free yogurt made using a galactose-positive exopolysaccharide-producing recombinant strain of Streptococcus thermophilus. Journal of Dairy Science, 92(2), 477-482. https://doi.org/10.3168/jds.2008-1312

Skryplonek, K., Henriques, M., Gomes, D., Viegas, J., Fonseca, C., Pereira, C., Mituniewicz-Małek, A. (2019). Characteristics of lactose-free frozen yogurt with $\kappa$-carrageenan and corn starch as stabilizers. Journal of Dairy Science, 102(9), 7838-7848. https:// doi.org/10.3168/jds.2019-16556

Subali, B. (2010). Analisis Statistika Menggunakan Program SPSS Aplikasinya dalam Rancangan Percobaan. Yogyakarta. Universitas Negeri Yogyakarta.

Tamime, A. Y., \& Robinson, R. K. (2014). Yoghurt Science and Technology. Oxford: Pergamon Press Ltd.

Tjokrokusumo, D. (2008). Jamur tiram (pleurotus ostreatus) untuk meningkatkan ketahanan pangan dan rehabilitasi lingkungan. Jurnal Rekayasa Lingkungan, 4(1), 53-62.

Widyastuti, N., Baruji, T., Isnawan, H., Wahyudi, P., \& Donowati, D. (2013). Analisa kandungan beta-glukan larut air dan larut alkali dari tubuh buah jamur tiram (Pleurotus ostreatus) dan shiitake (Lentinus edodes). Jurnal Sains Dan Teknologi Indonesia, 13(3), 182-191. https://doi.org/10.29122/js ti.v13i3.894 